\title{
An Analysis of the Link between Individual Identity Traits and Radical Party Choice
}

\author{
Alexandru Filip and Jan Lorenz (Jacobs University Bremen)
}

\begin{abstract}
While recent trends in the study of radial party voting have tended to focus on egalitarian attitudes and individual personality traits in their endeavor to explain radical party choice, the present study pits individual identity traits in the spotlight of ballot box behavior, using data from the World Values Survey and European Values Survey. We analyze the link between exclusive and inclusive identity (identifying with a more restricted ‘in-group’ versus identifying with a larger community) and the propensity to vote for radical right and radical left parties, using differences in individual identification with respondents' home nation and as European citizens. The results show that exclusive individual identity is a good predictor of radical right party choice, even in the presence of redistributive and egalitarian values usually associated with leftwing voting. The results also speak to the literature on welfare chauvinism. While the presence of strong egalitarian and redistributive attitudes does indeed normally predict radical left party preference in line with previous findings, this relationship is complicated by the presence of exclusive individual identity, which moderates the former's effect and can induce egalitarian voters to prefer radical right parties. In conclusion, the paper explores the interaction of identity and social class.
\end{abstract}

Keywords: Radical Political Parties, Individual Identity, Elections and Voting, Values, Welfare Chauvinism, Economic Preferences

\section{Funding}

The research and writing for this paper was conducted as part of the Research Project "Opinion Dynamics and Collective Decisions: Procedures, Behavior and Systems Dynamics” funded by the DFG (Deutsche Forschungsgemeinschaft), Grant Number 265108307.

This is an original manuscript of an article published by Taylor \& Francis in European Politics and Society, available online: http://www.tandfonline.com/10.1080/23745118.2020.1816007. 


\section{Introduction}

Radical political parties (from across the political spectrum) have been registering repeated successes in Western Democracies over the past decade. Their growth in recent years has been associated with populism and Euroscepticism on the back of growing apprehension with globalization (Meguid, 2008; Van Spanje, 2010; Schumacher and van Kersbergen, 2014; Hooghe and Marks, 2009; Kriesi et al, 2012; Teney et al, 2014). Their rise in support has also been interpreted as being fueled by the so called 'losers of globalization’(Betz, 1993; Swank and Betz, 2003; Kriesi et al, 2008; Van Elsas, 2017) and their discontent with the policies of mainstream parties, who are blamed for increased immigration, wage-depressing labor competition and the overseas outsourcing of services and production. While both the radical right and radical left oppose globalization and share an 'anti-mainstream' flavor, their underlying philosophies and appeals are different, especially on the cultural dimension(Marks and Wilson, 2000; Van Elsas and Van Der Brug, 2014). Explanations for differences in support for the radical left and right have varied from socio-economic to educational or cultural ones. Far too often the phenomenon has been explained by an 'issue salience’ mechanism, whereby radical party support is framed as a function of those issues that are most important to voters, be they reforms to economic structures or immigration policy. More recently, attempts have been made to reach a more 'underlying' understanding of such ballot box behavior by focusing on values and personality traits (Rooduijn et al, 2017; Bakker, 2016). This paper elaborates upon current models and going one step further with the inclusion of a factor that has so far received less attention in research on radical party support: the balance of inclusive and exclusive identity traits. In attempting to explain ballot behavior at a more 
fundamental level, we argue that the presence of inclusive and exclusive identity traits influences the propensity to vote for the radical right and radical left, and that it can moderate the effect of other factors on ballot choice, more precisely on 'altruistic' values such as egalitarianism and support for government redistribution (Rooduijn et al, 2017). Moreover, and in keeping with the moderating effect theme, we argue that such exclusive identity traits can help explain the proletarization of radical right constituencies: the tendency of ever growing numbers of (present and former) working class individuals to vote for radical right parties despite the resurgence of far left parties and candidates across Western Democracies (Harteveld, 2016). The paper commences with a brief discussion of the state of the art and previous research avenues in the exploration of radical party support. We then explain how our model elaborates and expands upon existing ones, introducing the main argument of the paper: that the balance of inclusive and exclusive identity traits of voters can explain support for radical right or radical left parties, over and beyond the 'standard' socio economic or cultural explanations.

Three hypotheses are presented, based on the 'identity' inference: that individual identity traits explain radical party voting, that they moderate the effect of 'altruistic' attitudes in explaining welfare chauvinism, and that they can help nuance the apparent paradox of working class and (traditional) labour constituencies’ support for the radical right.

After a short description of research design, the paper explores the direct effects of individual identity traits on the likelihood of voting for radical right and left parties (as opposed to mainstream parties, as well as opposed to each other), both as independent predictors as well as moderators of the effects of other variables, specifically altruistic attitudes and social class. 


\section{The Radical Right and the Radical Left}

The rise of radical parties in Western Europe has become an ever-present feature of modern politics, which a rich and growing literature has documented over the past decade and more (Mudde, 2004; Rydgren, 2005; Meguid, 2008; Van Spanje, 2010; Schumacher and van Kersbergen, 2014; Hooghe and Marks, 2009; De Vries and Edwards, 2009, March, 2011; March and Rommerskirchen, 2015). From UKIP success and Brexit to the rise of the Tea Party and the election of Donald Trump, from the surge of the far left in Southern Europe with Podemos and Syriza, to the growing strength of radical right parties such as the Lega Nord in Italy or the Front National in France, radical political parties and actors have over the past few years influenced many of Europe's political systems. In other European countries, such as those of the Benelux, Scandinavia or Germany, radical parties have not yet outright won elections but stand poised to become leading players in national politics in the coming electoral cycles.

The growing appeal of radical and fringe parties (be they from the left or right wing) is most commonly associated with discontent surrounding globalization and its more specific expressions: regional and European integration, immigration, heightened unemployment and labor competition, overseas job outsourcement, reduction in national sovereignty and control over national welfare policy (Kriesi et al, 2008, 2012; Szczerbiak and Taggart, 2008; Harteveld, 2016). Western Polities have reached a state wherein such parties are no longer seen as political outliers or pathologies, but as a (here-to-stay) 
feature of Western Democracy for the foreseeable short-term future (Mudde, 2016). Radical right and radical left parties share certain similarities and traits, despite their occupying fundamentally different positions in the political landscape: they tend to be Eurosceptic (Hooghe, Marks and Wilson, 2002), populist (Rooduijn and Akkerman, 2017) and some have nationalist tendencies (Halikiopoulou et al, 2012). Moreover, it has been found that the constituencies of such parties also often share certain traits: they tend to exhibit similar political discontents (especially caused by globalization) and tend to come from lower social strata (Visser et al, 2014), as in the 'losers of globalization’ thesis (Kriesi et al, 2008, 2012; Teney et al, 2014; Harteveld 2016).

Radical voting tendencies have been explained through a variety of factors, be they education and social background (Werts et al, 2013; Van Elsas, 2017), economic, or cultural ones(Lubbers and Jaspers, 2011). Some authors have sought to explain the tendencies to vote for either the radical right or radical left via an issue salience approach: if individuals are more concerned about the economic questions and issues of social policy, they would vote for the radical left, while those individuals more concerned about immigration will vote for radical right parties (Lefkofridi et al, 2014). The implication is that what sets apart radical right and radical left voters is the 'hierarchy' of issues (Weber and Saris, 2015), with voters turning to the two types of radical parties based on their weighing of the issues such parties own: immigration and security for the right, and socioeconomic concerns for the left. However, such explanations in a way just kick the problem 'down the road' without offering a more essential answer to the question of why different radical voters are more apprehensive about such different issues. One approach 
that answers the question to a such more 'fundamental' degree is the study of Rooduijn et al (2017). The authors' main argument is that radical left and radical right actors, and their voters, are (extreme) splinters of their wider political families, the right and left, and that the underlying philosophical foundations of such parties lie in taking said underlying ideological foundations to their extreme. Thus, what sets apart radical right and radical left voters are their (non-) altruistic and (non-) egalitarian attitudes and values. Radical left voters are highly egalitarian, altruistic and helpful, radical right voters are said to be the opposite: non-egalitarian and egoistic. That approach sets it apart from other studies, because it identifies the factors of radical party voting at a more 'underlying', personal, level. While Rooduijn et al's model is a highly valuable contribution and adds much analytical and theoretical value to the current state of the art, we consider it incomplete, because it ignores the possibility of individuals who are egalitarian and who are altruistic but wish to restrict the benefits of such values and attitudes to a narrower circle: in other words, welfare chauvinism. Our argument is that one important factor in determining whether voters will cast a vote for a radical party is constituted by an individual's identity traits: to what degree a voter displays inclusive or exclusive identity traits to be more precise, and we postulate that this directs how in-group out-group distinctions affect voters' ballot choice. The idea is not entirely novel, as previous research has shown that support of populist parties may lie more deeply in the psychological traits of individuals (Bakker et al, 2015). 


\section{Identity}

One strand of literature that seeks to explain political preferences and attitudes at a more fundamental level points to different identity traits among individuals in predicting their in-group/out-group perspectives. Hooghe and Marks (2004) and Mclaren (2007) have shown (measuring said identity traits via respondents self-descriptions and 'national', 'european', or 'both') that the presence of inclusive or exclusive identity traits can explain policy preferences and attitudes towards European Integration. It is important to note here that national identity and European identity are not in an inverse relationship. Previous research (Van Kersbergen, 2000; Risse, 2003) has shown that it is entirely possible to identify very strongly with one's own nation, or be very proud of it, and at the same time feel very proud of being European and identifying very strongly with other Europeans. National attachment and international/European attachment are not mutually exclusive, and do not follow a zero sum logic (Risse, 2003). It is possible for individuals to identify with several territorial communities simultaneously (Citrin and Sides, 2004; Klandermans et al, 2004), and to identify with larger groups of people than just their immediate surroundings or 'shared community of fate'. Some people (those with more inclusive identity traits) more easily identify with strangers or people from other countries, and will have a larger 'in-group' than those with exclusive identity traits, for whom it is hard to identify with anyone past their immediate community or nation. This latter type of voters is the kind that would normally identify themselves as 'only national'. Building on Greenfeld's work (1999) on individual identity traits and selfdignity, Kriesi (2009) suggests that some voter tendencies to opt for the far right might be best explained by calling into consideration the way national identity is constructed for various individuals. One could ask at this stage to what degree identity really is an 
exogenous factor (that is the operating assumption of the present study), or whether it is itself explained by something else, more latent and fundamental (in which case the results merely push the question up a level). While it cannot be claimed that identity is absolutely fundamental, invariable, and permanently stable, it is safe to assume that it is more 'fundamental' or 'primary' than most political positions or attitudes, or that the latter are less 'sticky' and stable than the former. As a thought experiment, one could postulate identity to be a function of very basic, fundamental things such as values, in the sense of the Schwartz human values structure(Schwartz, 1992), but even there it is hard to give a definitive answer - what past work has shown is that such values are more fundamental (and thus exogenous) than political attitudes (Beierlein et al, 2016). Cinpoes (2008) neatly summarizes the modernist claims that nations are modern constructs, that nationalism preceded the creation of nations (one could even talk of nations having been created by nationalism), and that nationalism is primarily a political ideology related to power and the establishment of the modern state (Hobsbawm, 1992). While such views take national identities to be creations (i.e. not anterior to political actions), they are compared to other political attitudes or beliefs - more stable, sticky, and enduring. That is moreso clear when one considers the long term processes involving memories, myths, values and symbols (Smith 1986, Anderson 1991) entangled in national formation. The process of European Identity construction has according to some also been a similar process, whereby elites tried to infuse a sense of identity to various communities, in a top-down phenomenon Risse, 2005. According to Tamir, the significance of national identities can be found in the ability to endow human action with meaning that endures across time. Accordingly, membership in a nation promises individuals redemption from personal oblivion, identification with a nation gives individuals hope of personal renewal through 
national regeneration, and membership in a nation offers rescue from alienation, solitude, and anonymity (Tamir, 1995). It is postulated here that such individuals who feel attachment (or a sense of belonging) to a larger community - and thus have a larger 'in-group' - do not perceive their community or in-group as being under as big a threat, and can thus allow themselves to be more concerned with socioeconomic questions than with the cultural ones underscoring the national 'shared community of fate'. Individuals with highly exclusive identity traits on the other hand have a smaller 'in-group' and are more likely to perceive it as being under threat by globalization and immigration. For them, the sense of urgency is greater when it comes to 'protecting' the community they identify with and concerns of economic reform take a back seat.

It is this type of individual identity traits which we expect makes individuals more susceptible to cultural fears and concerns over immigration than economic ones. Thus, it is implied that such voters are the ones who would more likely support welfare chauvinism and express their discontent with globalization by voting for the radical right, instead of the radical left. Hypothesis 1 (Identity Traits’ Hypothesis): Exclusive and Inclusive Identity traits explain radical vote tendencies, with exclusive identity traits correlating with radical right voting and inclusive identity traits with radical left voting.

One phenomenon whose scope exceeds the material possibility of this paper but merits discussion is that of the interaction between the supply and demand of policy, and 'political space'. Not only has the diminishing support for centrist and established parties in the $21^{\text {st }}$ century been attributed to the 'losers of globalization', the 'cartelization' of 
mainstream parties and their perceived fossilization has also been said to fuel the rise of political fringes. Accordingly, the next stage in the evolution of political parties after Kirchheimer's 'catch-all parties' was that of 'cartel parties' Mair and Katz (1995) in the sense that mainstream parties formed a type of centrist 'cartel', a process involving a merger with state structures, disconnection with grass-roots and mass politics, and growing out of touch with voters. Christian democratic parties lost their conservative character, while social democratic parties inched ever closer to the neoliberalism of the economic center. According to Van Biezen, center parties came to resemble in a way public utilities in the delivery of governance (2004). Past work has suggested that alienation with mainstream parties (Parteivedrossenheit) can be seen as a major culprit for protest voting and the rise of fringe parties (Mair, 2001). Not only did said cartelization alienate voters, the shift by the historical 'Volksparteien' created an open/available opportunity space for radical policy entrepreneurs to occupy and take advantage of (Spies and Franzmann, 2011). It is somewhat hard to address this given the data, whose focus lies with voters. A proxy for this is the 'trust in parties', since. This is, admittedly, not an optimal avenue to measure attitudes towards mainstream politics, but it carries the advantage that individuals who are 'turned off' by mainstream party cartelization are likely to be alienated and less trustful of political of politicians and parties. Arguably, identity can become more or less salient under differing circumstances. At this point it is perhaps opportune to discuss one of the shortcomings of the analysis in the paper: the issue of 'identity entrepreneurs'. After all, a significant part of the Postfunctionalist Theory on European Integration, which has come to play such a large part of the EU research agenda, admits that the shift from economic to ideational political 
contestation over Europe is partly due to certain political actors mobilizing the identity cleavage ( as Europeanization and Globalization as threats to national identity and culture) to advance their own political position. As Kriesi himself states about populist and radical parties in their roles as identity entrepreneurs “: (...) the basis of their success lies in their appeal to identity and their exploitation of anxieties about losing one's identity in a denationalizing world. These parties are so successful, because they successfully prime, frame or cue national identities. But why does the framing of these parties resonate so well with the losers of denationalization processes?”(Kriesi 2008, 224) Unfortunately, the structure of the data does not allow a verification of change across time. The latest wave of the European Values Study would have constituted a wonderful opportunity to study to what degree the effect of identity on party preferences changes or varies over time. (Sadly, the questions and variables on identity that are at the heart of this paper are not present in it.)

\section{Welfare Chauvinism}

To continue the previous line of thought, we assume that the identity factors can explain welfare chauvinistic attitudes. It is feasible for people to be highly egalitarian, altruistic, and favor government redistributive social policy, but to wish for equality and redistribution among their co-nationals while seeking to deny non-nationals said equality (Marx and Naumann, 2018; Schumacher and Van Kersbergen, 2014). Existing research has confirmed the presence of welfare chauvinistic attitudes among the electorate 
(Goerres et al, 2018; van der Waal, 2010) according to which individuals profess a preference for the redistributive welfare state, but which restricts access to it to it. We argue here that welfare chauvinism may be tied to the above mentioned exclusive identities. It is entirely possible for individuals to be altruistic and egalitarian deep down, but to believe that such altruism does not deserve to be extended beyond the immediate in-group. Rooduijn et al (2017) show that 'altruistic' values, such as egalitarianism and the belief that the government should reduce wealth inequalities are associated with voting for the left, while voting for the right is a function of the opposite values: radical right voters are supposedly non-altruistic and non-egalitarian. We hypothesize that the presence of exclusive identity traits could moderate the relationship between altruistic values and ballot choice behavior. While we expect the 'baseline' effect of altruistic, redistributive values to be one of increasing support for the radical left and diminishing support for the radical right, these can have the opposite effect when combined with exclusive identity traits. "Hypothesis 2" predicts that at very exclusive identity levels, even highly equalitarian individuals and those supporting government redistribution will have a smaller likelihood of voting for the radical left and a higher likelihood of voting for the radical right.

\section{The Proletarization of the Radical Right}

The working class has traditionally been regarded as the constituency of labor and socialist parties, and despite the acknowledgement that some individuals cultural fears outweigh class alignment on the economic on redistributive concerns, it has been 
disquieting to the European left to witness the 'proletarization' of the radical right vote, i.e. the growing defection of such voters to the far right instead of far left, or new socialist parties in their opposition to globalization. Traditionally, unions and the working classes relied on labour parties and socialist parties to further their interest (Skocpol and Amenta, 1986) in the fight over political economy, while bourgeois, self-employed and rural electorate were more likely to be swayed by political positions coming from the right. The Left and the Right have faced globalization and integration logics in reverse: Socialist and communist parties have historically pursued policies of economic protectionism while adopting more inclusive social and cultural policies, whereas right wing parties have traditionally promoted market liberalization, welfare stateretrenchment, and cultural protectionism (Marks and Wilson, 2000; Van Elsas and Van Der Brug, 2014). On the right many parties favored economic liberalization and welfare state retrenchment, with many right wing parties (Lega Nord, The Progress Party) starting out as parties with a pro-market, anti-tax, anti-statist focus) - a policy position inimical to left-wing voters. Until the turn of the millennium, communist and socialist parties were often stronger critics of globalization and European Integration than right wing parties (Marks and Wilson, 2000; Hooghe Marks and Wilson, 2002), and some far right parties actually supported international influence that weakened the grip of the central state, for example in Italy and Austria.

In the 1990's it became fashionable to talk of a 'winning formula' for right wing parties combining market-favoring neoliberal policies and opposition to immigration (Kitschelt and McGann, 1995), such as the Austrian Freedom Party, the Italian Lega Nord or the 
Danish Freedom Party. This was predicated on the typical view of the time of right wing voters: conservative, economically successful individuals (self-employed, business owners, rural constituencies). Lately this assumption has been challenged by observations all over the European Political space of growing support for the right wing among the working class, traditionally the constituency of organized labor and socialist parties in post war Europe, be they 'center left' or 'far left'. De Lange (2007), and McGann and Kitschelt (2005) offered an updated, different vision on the winning formula, combining right wing conservative, chauvinistic, authoritarian cultural positions with left-leaning economic policies. This has coincided with a movement towards the left - economically - by far right parties, who now espouse the protection of social policies and the welfare state. In the present day, support of radical right parties comes not only from traditional 'right wing' constituencies, but increasingly the working class as well (Ivarsflaten, 2005).

A multitude of studies have attested to this phenomenon wherein ever more voters who formed the constituency of socialist parties (working class voters and other left-leaning persons) are now taking their votes to the far right pole of Europe's political ecology (Lubbers et al, 2002; Ivarsflaten, 2005; McGann and Kitschelt, 2005; Rydgren, 2005; Arzheimer, 2008; Harteveld, 2016). While it is no large surprise that working class and lower class individuals support far right parties given the latter's opposition to globalization ('the losers of globalization thesis'), many authors have continued to emphasize that this runs counter to the expectations of political ideology, especially considering the resurgence of the radical left and populist left over the past decade (Oesch, 2008; Spies, 2013). The political party landscape in Europe has been flattened by 
the defection of mainstream voters not only to the radical right but also the radical left, which is also challenging the political mainstream. 'Left Liberals' still exist, and Van der Brug and Van Spanje (2009) and Thomassen (2012) have shown that while some leftwing voters do exhibit authoritarian traits (and vote on the basis of the cultural threat issue), plenty are leftist-liberal, or continue to vote in favor of the left wing (March, 2011; Gomez et al, 2016).

Spies (2013) has asked how we can explain the paradox of voters, who are traditionally considered as holding left-wing oriented political preferences, voting for parties on the extreme right? The paradox was also observed by Oesch (2008), who stated that the alliance between right populist parties and workers is remarkable, given that it runs counter to common wisdom about class voting, whereby individuals strongly opposed to labour market risk or working class individuals are expected to be more likely to vote for parties on the left than right. Why should the working class' cultural concerns be stronger than their socio-economic ones in the 'hierarchy of issues'? Why is it so common for blue-collar workers in Europe (the losers of globalization) to not vote for far left opposition to globalization instead of far right opposition? In keeping in line with the arguments made in the previous two sections, we expect that for those individuals with inclusive identity traits, class alignment will trump national alignment in determining the vote. Such voters will express their opposition to globalization by casting a radical left ballot. For those individuals that are characterized by exclusive traits, class alignment will matter less than national sentiment, and they will thus pick the radical right.

Since it is assumed that class alignment would dictate working class and blue-collar voters to voter for socialist and left wing parties, and since no such assumption is made 
about other social classes, we hypothesize that exclusive and inclusive identity traits should have a bigger effect in determining radical right vote among the working and lower middle class than among other individuals, such as upper class people (since the latter would need less incentive to vote for the right than constituencies that historically voted left). "Hypothesis 3" predicts that identity inclusiveness and exclusiveness should affect the voting tendencies of the working class and lower middle class: individuals from these social classes with exclusive identities will vote for the radical right, while those with inclusive identities will vote for the far left.

\section{Data and Method}

The data used here comes from the World Values Survey and European Values Survey ${ }^{1}$, specifically the last two waves (2005 - 2009 and 2010 - 2014). While the Eurobarometer at times also included questions probing relative identity traits, the question has unfortunately not been asked lately and not in combination with vote intention/behaviour queries. The World (and European) Values Surveys does include such measures in the last two waves, in parallel with vote-intention questions - the paper will thus include data from these two most recent waves (2005 - 2009 and 2010 - 2014). Exclusive and inclusive identity traits are measured using two indicators of the European and World Values Surveys: the values of the national identity indicator(I see myself as citizen of the [country] nation) are subtracted from the European one (I see myself as citizen of the [European Union]), generating a new variable that measures the difference between an

1 Ingelhart et al, 2014 
individual's European identification and national identification ${ }^{2}$. The data - when considering all the indicators and variables included - is available for seven countries: Finland, Germany, Spain, Sweden, Norway, Switzerland, and the Netherlands - these are the West European Countries for which the required data is available. ${ }^{3}$ The study designates Political Parties as Radical Right or Radical Left in accordance with the Chapel Hill Expert Survey (Bakker et al, 2015; Polk et al, 2017), wherein country experts are asked to attribute political parties to one of several party families (for example radical right, radical left, liberal, social democratic, Christian democratic, etc). ${ }^{4}$ Dummy (binary) variables were generated to describing vote choice as dependent variables. Three types of models are presented over the course of the analyses based on the three dependent variables: in the first type, the binary response is coded 1 if the voter opted for a radical right party and 0 if else. Thus, the model measures the likelihood of voting for a radical right party. Model type two's dependent variable is coded 1 if respondents voted for a radical left party, and 0 if else, thus the model measures the probability of voting for the radical left against voting for all other parties. Model type three only includes those

2 Since both values range from 1 to 4 (strongly agree to strongly disagree), the combined Identity variable ranges from -3 to +3

3 Cases for Netherlands only become available when not controlling for attitudes towards immigration (see table 4 in the Appendix). While the main analysis does control for attitudes to immigration, the Appendix presents the results when that is omitted, The results of the analysis remain the same.

4 In some few instances, the world values survey contains ballot choice responses of parties too small or insignificant for the Chapel Hill Survey: for example parties like the NPD or DVU. For such small parties, the decision on whether to designate them radical right or radical left was taken on the basis of the ParlGov database (Döring and Manow 2018) 
voters who voted for either the radical left and the radical right - the indicator thus measures the likelihood of voting for a radical right party as opposed to a radical left one ( 0 ' if the voter opted for the radical left, and ' 1 ' if the choice was for the radical right). The variable measuring "support for government redistribution" gets its data from the integrated Values Survey’ variable E037 ‘Government Responsibility’, where answers run on a scale ranging from "Individuals should take more responsibility for providing for themselves" to "The state should take more responsibility to ensure that everyone is provided for". The variable measuring support for equality(egalitarianism) is based on variable E035 “Income Inequality”. The scale is reversed (due to how it was recorded in the survey) and the scale thus ranges from "We need larger income differences as incentives” to “Incomes should be made more equal”.

Control variables include education levels and employment status, country dummies, as well as a variable for individual attitudes towards immigration. Further indicators from the Values Surveys control for individual gender, age, economic satisfaction, subjective social class, religiosity, political trust. Country dummies control for country-based variation while a country-survey wave cluster variable (S024) allows for cluster-robust logistic regression ${ }^{5}$. Due to limitations pertaining to data (the degree to which survey questions were posed in all countries, the presence in some countries of parties from both the radical right and the radical left, etc), not all countries make their way in the final regression tables, and not all country dummies appear in each model, as they are sometimes dropped by the logistic regression.

5 A table describing the operationalization of all variables included in our models can be found in the appendix 
A further shortcoming of the present study is in relation to crises (both the financial and the refugee crisis) the crises which arguably had an effect on the psyche of Europeans and their tendencies to feel 'togetherness'. As is the case with a few other issues, the nature of the data does not permit a tackling it appropriately, given the poor longitudinal traits of the data. For the two values' study waves which enquired about identity (both national and European), data was collected between the years 2005 and 2013. In the case of the migration crisis, it represents a time point too early, since 2015 was the year of the contentious peak. As for the financial crisis, 76\% of observations were collected by 2009 (the year with the onset of the European debt crisis), 85\% of the observations by 2011, and $92 \%$ by 2012, when Greece received its second Euro bailout. This is amplified by the fact that only 4 countries are present in the second wave. Too few observations and clusters of data remain to explore the effect of attitudes towards PIIGS bailouts on party choice.

\section{Empirical Results}

Regression Table ' 1 ' shows the output from two types of analysis, each with three models. The first type replicates (albeit with different data - World Values Survey data as opposed to ESS data) past research done on the electorates of the radical right and radical left, more specifically that of Rooduijn et al (2017), which find that altruistic values are associated with radical party voting. Like in previous work, altruistic values correlate strongly with radical left voting, and the largest, most significant effects are found when comparing radical right and radical left voters in model 3(the likelihood of voting for a radical right party vs a radical left party). 
Models "4" through "6" add the identity traits' indicator to the models, and reveal output in line with the expectations derived from the first models. The relative structure of individuals' inclusive and exclusive identity traits is significantly correlated with radical right voting, but little so when examining the probability of voting for the far left as opposed to mainstream parties. The identity variable once again becomes significant when comparing in model 6 radical right voting against the benchmark category of radical left voting: the more exclusive an individual's identity structure is, the more likely it is that she will vote for the radical right, while those with inclusive identities will vote for the far left, in line with hypothesis 1 . It is noteworthy to mention that the results of the other coefficients (control variables) remain very stable across the models, even when adding the effect of identity to the equation.

We notice that education is, across the board, positively correlated with voting for the far left and negatively correlated with voting for the far right. Gender is only significant when it comes to voting for the radical right vs the mainstream and the radical right vs the radical left (but not in models 2 and 5, related solely to the left): men are more likely to vote for the far right than women are. The latter two outcomes both back up previous findings in the literature on Euroscepticism and populist studies (Van Elsas 2017) showing that men and the less educated are likely to support right wing eurosceptic parties, while women and the better educated are more likely supporters of left wing Euroscepticism. The relationship of age with party support is statistically significant but 
rather weak. Nevertheless, the coefficients, meagre as they are, point to the unexpected situation in which younger voters are more likely to vote for the far right and older voters are expected to vote for the far left. A quadratic term is added, to test whether age has a non-linear effect of party preference, with the result being negative. The effect of immigration attitudes goes in the expected direction in all models. Having a positive attitude towards immigration is associated with radical left support, while a negative attitude correlates with radical right support. Two variables that are significant in some but not all models are trust in political parties and the effect of being religious. In the case of the latter, the coefficient is significant in the models exploring the radical left and radical right vs radical left, but not the models focusing on the radical right by itself. This suggests that the effect of (absence of) religiosity is more related to radical left support than right wing support. In the case of trust for political parties, which can be read as a proxy for approval of the country's political mainstream, the coefficient becomes significant in the first and third model of each triad, suggesting the it is related to support for the radical right (vs the mainstream, and vs the radical left): right wing voters are less likely to trust political parties. Unemployment correlates positively with support of both the radical right and radical left in both model triads (being unemployed increases the chances of supporting radical parties generally). In model Six we also observe that unemployment becomes marginally significant with a negative sign - being unemployed is negatively correlated with voting for the right as opposed to the left, when controlling for identity differences. This could be attributed to the promise of social policy from the left being more consistent and having a stronger appeal for those out of a job. 
Table 1

\begin{tabular}{|c|c|c|c|c|c|c|}
\hline & M1 & M2 & M3 & M4 & M5 & M6 \\
\hline & Rad right v & Rad left v & Rad right v & Rad right v & Rad left v & Rad right $\mathrm{v}$ \\
\hline VARIABLES & Mainstream & Mainstream & Rad left & Mainstream & Mainstream & Rad left \\
\hline \multirow[t]{2}{*}{ Identity Difference } & & & & $-0.52 * *$ & 0.12 & $-0.58 * * *$ \\
\hline & & & & $(0.195)$ & $(0.075)$ & $(0.120)$ \\
\hline \multirow[t]{2}{*}{ Egalitarianism } & -0.05 & $0.14^{* * *}$ & $-0.18 *$ & -0.05 & $0.15^{* * *}$ & $-0.21^{*}$ \\
\hline & $(0.045)$ & $(0.033)$ & $(0.088)$ & $(0.047)$ & $(0.027)$ & $(0.089)$ \\
\hline \multirow[t]{2}{*}{ Gov. Redistribution } & -0.10 & $0.13^{* * *}$ & $-0.21^{*}$ & $-0.10^{*}$ & $0.12 * * *$ & $-0.19 *$ \\
\hline & $(0.061)$ & $(0.030)$ & $(0.088)$ & $(0.046)$ & $(0.030)$ & $(0.079)$ \\
\hline \multirow[t]{2}{*}{ Education } & $-0.20 * * *$ & $0.20 * * *$ & $-0.44^{* * *}$ & $-0.19 * * *$ & $0.20 * * *$ & $-0.44 * * *$ \\
\hline & $(0.025)$ & $(0.057)$ & $(0.097)$ & $(0.022)$ & $(0.056)$ & $(0.107)$ \\
\hline \multirow[t]{2}{*}{ Unemployed } & $1.02 * * *$ & $0.61^{* *}$ & -0.31 & $1.11^{* * *}$ & $0.61^{* * *}$ & $-0.38 *$ \\
\hline & $(0.147)$ & $(0.190)$ & $(0.172)$ & $(0.187)$ & $(0.178)$ & $(0.168)$ \\
\hline \multirow[t]{2}{*}{ Male } & $0.41 * * *$ & -0.21 & $0.74^{* * *}$ & $0.33^{* * *}$ & -0.20 & $0.59 *$ \\
\hline & $(0.099)$ & (0.199) & $(0.210)$ & $(0.038)$ & $(0.207)$ & $(0.264)$ \\
\hline \multirow[t]{2}{*}{ Age } & $-0.08 * * *$ & $0.04 *$ & $-0.11^{*}$ & $-0.09 * * *$ & $0.04^{*}$ & $-0.12 * *$ \\
\hline & $(0.013)$ & $(0.017)$ & $(0.048)$ & $(0.015)$ & (0.018) & $(0.041)$ \\
\hline AgeSquared & $0.00 * * *$ & -0.00 & $0.00 *$ & $0.00 * * *$ & -0.00 & $0.00 *$ \\
\hline
\end{tabular}




$\begin{array}{lcccccc} & (0.000) & (0.000) & (0.000) & (0.000) & (0.000) & (0.000) \\ \text { Religious } & -0.02 & -0.88^{*} & 1.04^{* * *} & 0.00 & -0.88^{* *} & 1.17^{* * *} \\ & (0.083) & (0.363) & (0.202) & (0.064) & (0.341) & (0.274) \\ \text { Economic Satisfaction } & -0.01 & -0.00 & -0.06^{* *} & -0.01 & -0.01 & -0.06^{*} \\ & (0.021) & (0.029) & (0.023) & (0.021) & (0.026) & (0.024) \\ \text { Trust in Political Parties } & 0.27^{* *} & -0.07 & 0.90^{* * *} & 0.26^{*} & -0.08 & 1.01^{* * *} \\ & (0.083) & (0.143) & (0.152) & (0.104) & (0.133) & (0.148) \\ \text { Immigration Attitude } & 1.05^{* * *} & -0.21^{* *} & 1.17^{* * *} & 1.00^{* * *} & -0.18^{*} & 1.08^{* * *} \\ & (0.146) & (0.071) & (0.298) & (0.155) & (0.069) & (0.316) \\ \text { Constant } & -6.08^{* * *} & -4.47^{* * *} & -0.26 & -6.38^{* * *} & -4.45^{* * *} & -0.51 \\ & (0.649) & (0.550) & (2.441) & (0.585) & (0.546) & (2.658)\end{array}$

country fixed effects are

included but not reported

Observations

Pseudo R-squared
4,171

0.22
5,899

0.14
657

0.53
4,078

0.25
5,666

645

0.14

0.55

$$
\text { *** } \mathrm{p}<0.001, * * \mathrm{p}<0.01, * \mathrm{p}<0.05
$$

Table " 1 " showing the 'basic' models derived from existing literature(models ' 1 ' to ' 3 ') which include only the 'redistributive attitudes' variables and 'control' variables (including attitudes, demographic information, etc.) Models ' 4 ' to ' 6 ' adds the Exclusive Identity variable to the each model. In both 'sets' of models, the first one focuses on radical right voting vs all other voters, the second one focuses on radical left voting versus all other, and the third one focuses on radical right versus radical left voting. Country dummies and social class dummies not reported. Complete Table in Appendix

The data for models 1 through 6 comes from six countries: Finland, Germany, Norway, Switzerland, Spain and Sweden. The models get more observations (from the Netherlands, and one of the two waves in Sweden) when the control variable from immigration attitudes is dropped. This is because questions probing attitudes towards immigration were not asked in the cases of the Dutch and one of the Swedish survey waves. Even when not controlling for such attitudes, the main results remain the same and the effects do not change - exceptions constitute the unemployment and demographic indicators which lose some statistical significance due to increased standard errors (the increased standard errors influence those effects that had the weakest significance). That output is presented in table 4 of the Appendix. 
Building on the inferences from models one through six, we test Hypothesis 2 about the interaction between identity traits and egalitarian attitudes. We present six models: two types of interaction (one with egalitarianism and one with redistributive preferences) are present for each of the three binary response variables (radical right voting, radical left voting, radical right versus radical left), depicted in table 2. The coefficients tend to retain their strength and significance levels, when accounting for the added interactions. In fact, the only coefficients which change (from models 4-6 to the ones with the interaction terms) are those of the variables included in the interactions themselves. Given their inclusion in the interactions, the interpretation of said coefficients changes from table 1 to table 2. Given the presence of the interaction terms, the coefficients in the table (2) for the constitutive terms are of less substantive interest (Brambor et al, 2006). In the cases in which Identity difference is used in an interaction, the simple coefficient for Identity difference becomes the effect of said variable on voting tendency when the value of the other item in the interaction, be it egalitarianism or support for redistribution, is zero (and vice versa). Moreover, as Brambor et al have noted, “it cannot be inferred whether $X$ has a meaningful conditional effect on $Y$ from the magnitude and significance of the coefficient on the interaction term (...) it is perfectly possible for the marginal effect of $X$ on $Y$ to be significant for substantively relevant values of the modifying variable $Z$ even if the coefficient on the interaction term is insignificant (...) It means that one cannot determine whether a model should include an interaction term simply by looking at the significance of the coefficient on the interaction term" (Brambor et al, 2006, 74). 
Therefore, we focus on the subsequent margins plots depicting the marginal effects of redistributive and egalitarian attitudes at representative values of interest.

Table 2

\begin{tabular}{|c|c|c|c|c|c|c|}
\hline & M7 & M8 & M9 & M10 & M11 & M12 \\
\hline & Rad right $\mathrm{v}$ & Rad left v & Rad right $\mathrm{v}$ & Rad right $\mathrm{v}$ & Rad left v & Rad right $\mathrm{v}$ \\
\hline VARIABLES & Mainstream & Mainstream & Rad left & Mainstream & Mainstream & Rad left \\
\hline \multirow[t]{2}{*}{ Identity Difference } & -0.35 & 0.39 & $-0.72 * * *$ & $-0.90 * * *$ & -0.06 & -0.88 \\
\hline & $(0.297)$ & $(0.228)$ & $(0.200)$ & $(0.122)$ & $(0.334)$ & $(0.462)$ \\
\hline \multirow[t]{2}{*}{ Egalitarianism } & -0.07 & $0.13^{* * *}$ & $-0.20 *$ & -0.05 & $0.15^{* * *}$ & $-0.20 *$ \\
\hline & $(0.047)$ & $(0.035)$ & $(0.097)$ & (0.049) & $(0.027)$ & $(0.083)$ \\
\hline \multirow[t]{2}{*}{ Gov. Redistribution } & $-0.10^{*}$ & $0.12 * * *$ & $-0.19 *$ & -0.04 & $0.13^{* *}$ & -0.16 \\
\hline & $(0.046)$ & $(0.031)$ & $(0.080)$ & $(0.053)$ & $(0.050)$ & $(0.097)$ \\
\hline \multirow[t]{2}{*}{ Education } & $-0.18^{* * *}$ & $0.20 * * *$ & $-0.44 * * *$ & $-0.19 * * *$ & $0.20^{* * *}$ & $-0.44 * * *$ \\
\hline & $(0.022)$ & $(0.056)$ & $(0.105)$ & $(0.022)$ & $(0.056)$ & $(0.108)$ \\
\hline \multirow[t]{2}{*}{ Unemployed } & $1.08^{* * *}$ & $0.61 * * *$ & $-0.37 *$ & $1.12^{* * *}$ & $0.61^{* * *}$ & $-0.36^{*}$ \\
\hline & $(0.202)$ & $(0.180)$ & $(0.145)$ & $(0.181)$ & $(0.179)$ & $(0.158)$ \\
\hline \multirow[t]{2}{*}{ Male } & $0.34 * * *$ & -0.20 & $0.58^{*}$ & $0.34 * * *$ & -0.20 & $0.59 *$ \\
\hline & $(0.034)$ & $(0.207)$ & $(0.267)$ & $(0.030)$ & $(0.207)$ & $(0.272)$ \\
\hline \multirow[t]{2}{*}{ Age } & $-0.09 * * *$ & $0.04 *$ & $-0.12 * *$ & $-0.09 * * *$ & $0.04 *$ & $-0.12 * *$ \\
\hline & $(0.014)$ & (0.018) & (0.043) & $(0.013)$ & (0.018) & $(0.040)$ \\
\hline \multirow[t]{2}{*}{ AgeSquared } & $0.00 * * *$ & -0.00 & $0.00^{*}$ & $0.00^{* * *}$ & -0.00 & $0.00 *$ \\
\hline & $(0.000)$ & $(0.000)$ & $(0.000)$ & $(0.000)$ & $(0.000)$ & $(0.000)$ \\
\hline \multirow[t]{2}{*}{ Religious } & 0.00 & $-0.88 *$ & $1.17 * * *$ & 0.01 & $-0.88^{* *}$ & $1.17 * * *$ \\
\hline & (0.063) & (0.343) & $(0.271)$ & (0.068) & $(0.340)$ & $(0.280)$ \\
\hline Economic Satisfaction & -0.01 & -0.00 & $-0.06 *$ & -0.02 & -0.01 & $-0.06 * * *$ \\
\hline
\end{tabular}




$\begin{array}{lcccccc} & (0.020) & (0.025) & (0.025) & (0.017) & (0.027) & (0.017) \\ \text { Trust in Political Parties } & 0.25^{*} & -0.08 & 1.02^{* * *} & 0.26^{* *} & -0.08 & 1.03^{* * *} \\ & (0.106) & (0.132) & (0.142) & (0.099) & (0.132) & (0.137) \\ \text { Immigration Attitude } & 1.00^{* * *} & -0.18^{* *} & 1.08^{* * *} & 1.00^{* * *} & -0.18^{*} & 1.11^{* * *} \\ & (0.155) & (0.068) & (0.316) & (0.153) & (0.069) & (0.298) \\ \text { ID Difference*Egalitarianism } & -0.03 & -0.04 & 0.02 & & & \\ & (0.02) & (0.027) & (0.042) & & & \\ \text { ID Difference*Gov. Redistribution } & & & & 0.08^{*} & 0.03 & 0.05 \\ \text { Constant } & & & & (0.035) & (0.048) & (0.080) \\ & -6.22^{* * *} & -4.30^{* * *} & -0.57 & -6.80^{* * *} & -4.56^{* * *} & -0.97 \\ & (0.536) & (0.565) & (2.567) & (0.741) & (0.683) & (2.385)\end{array}$

country fixed effects are

included but not reported

$\begin{array}{lcccccc}\text { Observations } & 4,078 & 5,666 & 645 & 4,078 & 5,666 & 645 \\ \text { Pseudo R-squared } & 0.25 & 0.14 & 0.55 & 0.25 & 0.14 & 0.55\end{array}$

Robust standard errors in parentheses

$* * * \mathrm{p}<0.001, * * \mathrm{p}<0.01, * \mathrm{p}<0.05$

Table 2, depicting the models with interaction effects for the 'Exclusive Identity' variable and variables measuring egalitarian and redistributive values. The first set of models (7 to 9) include the interaction between the Identity variable and attitudes towards government redistribution, while the latter three include the interaction with egalitarianism. *Country dummies and social class dummies not included *Complete table in appendix

We focus our attention on the predictive margins in figures 1 through 6 . We begin with 
radical left voting, since existing literature, as well as our own initial empirical output, show that egalitarian and 'altruistic' values are expected to be a stronger predictor of whether one voters for a radical left party (as opposed to a another type of party) than for radical right parties. Each of the 6 figures below contain multiple predictive margins lines, each corresponding to varying types of voters: highly equalitarian/redistributive, and anti-egalitarian/redistributive. These predictive margins lines trace the effect of said indicators (high and low values) across the entire range of exclusive (-3 on the graphs) to inclusive (3) identity traits.

Figure 1

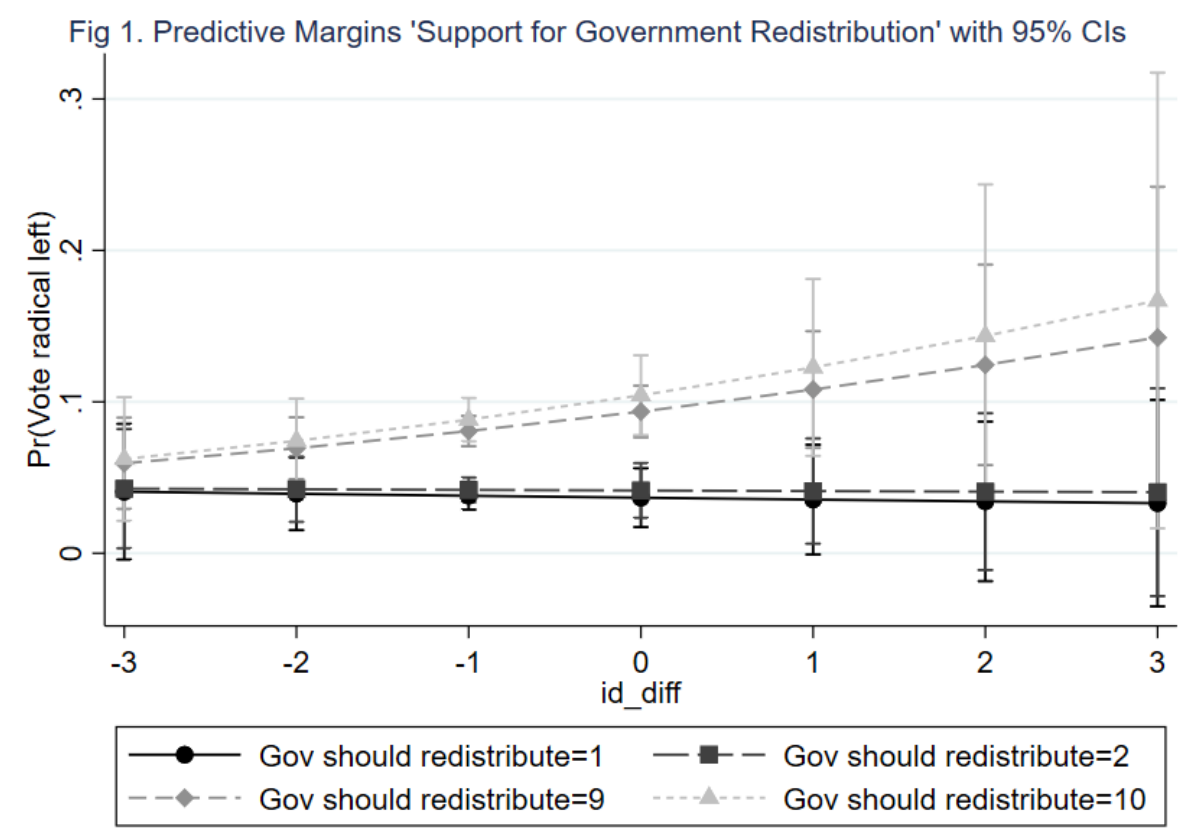

The Interaction between the attitudes towards government redistribution and Identity traits affecting the odds of voting of voting for a radical left party. Negative numbers (left) on the horizontal axis represent exclusive identity traits while positive numbers depict highly inclusive traits. High numbers on the equality variable represent people who believe "The state should take more responsibility to ensure that everyone is provided for", while low values represent the opposite. 
Figure 2

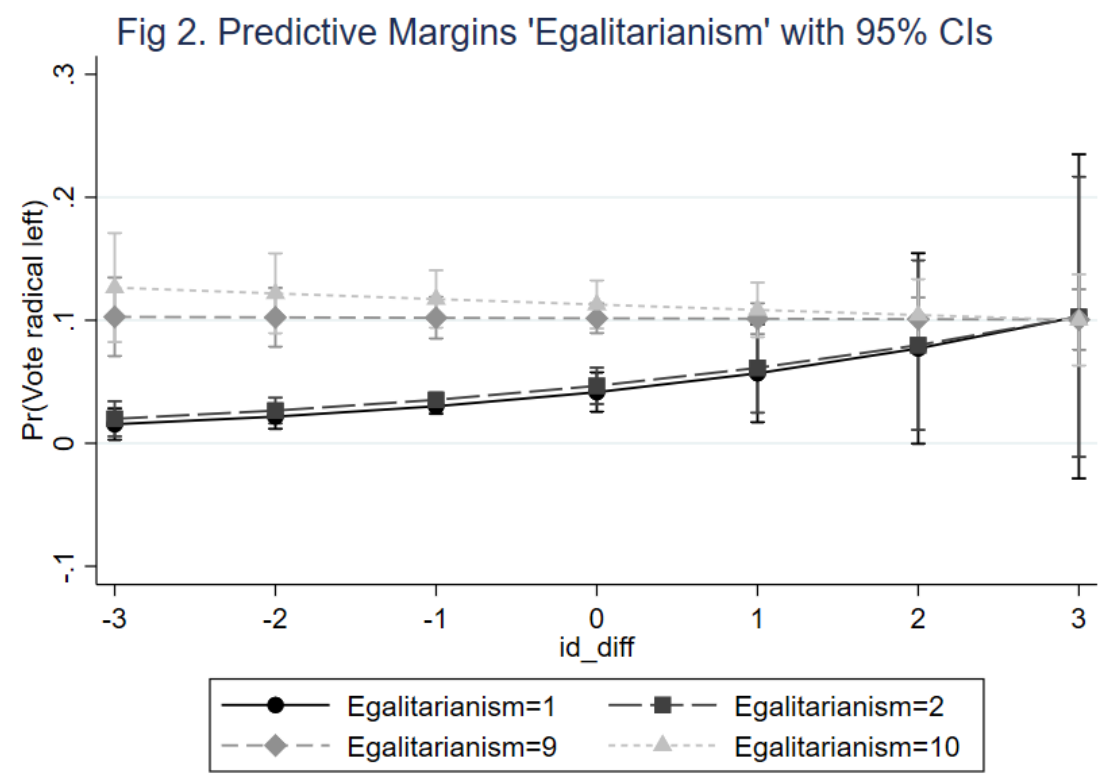

The Interaction between the attitudes towards Income inequality and Identity traits affecting the odds of voting of voting for a radical left party. Negative numbers (left) on the horizontal axis represent exclusive identity traits while positive numbers depict highly inclusive traits. High numbers on the egalitarian variable represent people who believe "Incomes should be made more equal", while low values represent respondents who think "We need larger income differences as incentives".

Figure 1 shows that under circumstances of exclusive identity, the likelihood of voting for the radical left is close to zero for both individuals who believe the government is responsible for redistributing wealth and for those who believe the government has no responsibility. As we move right on the graph (towards more inclusive identity traits), the prediction for anti-redistributive voters remains close to zero, but the one for redistributive favoring voters goes up with every tick right on the graph. Unfortunately, the standard errors on that side become too large at high inclusive identity levels due to the smaller number of cases compared to the other levels (which leads to the confidence 
intervals of the two predictions crossing each other), but given the steady slope on the prediction (up to that point) it is expected that among voters strongly in favor of government redistribution, the probability of voting for the radical left grows with the degree of identity inclusivity, and decreases in the opposite direction, in accordance with hypothesis 2. Figure 2 shows a similar graph, but with attitude towards equality replacing those towards redistribution. Contrary to the predictions of hypothesis 2, we do not find a significant interaction between the two variables: egalitarian voters do not become significantly less likely to vote for the radical left when displaying exclusive identity traits.

Figure 3

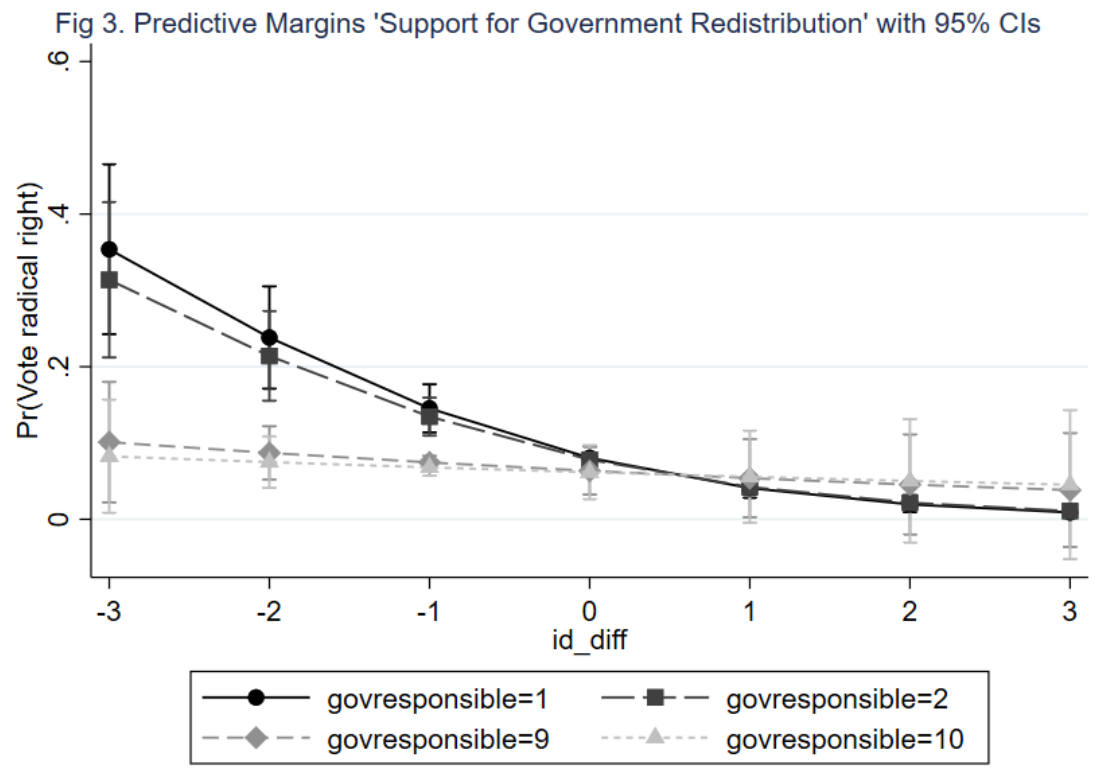

The Interaction between the attitudes towards government redistribution and Identity traits affecting the odds of voting of voting for a radical right party. Negative numbers (left) on the horizontal axis represent exclusive identity traits while positive numbers depict highly inclusive traits. High numbers on the equality variable represent people who believe "The state should take more responsibility to ensure that everyone is provided for", while low values represent the opposite. 
Figure 4

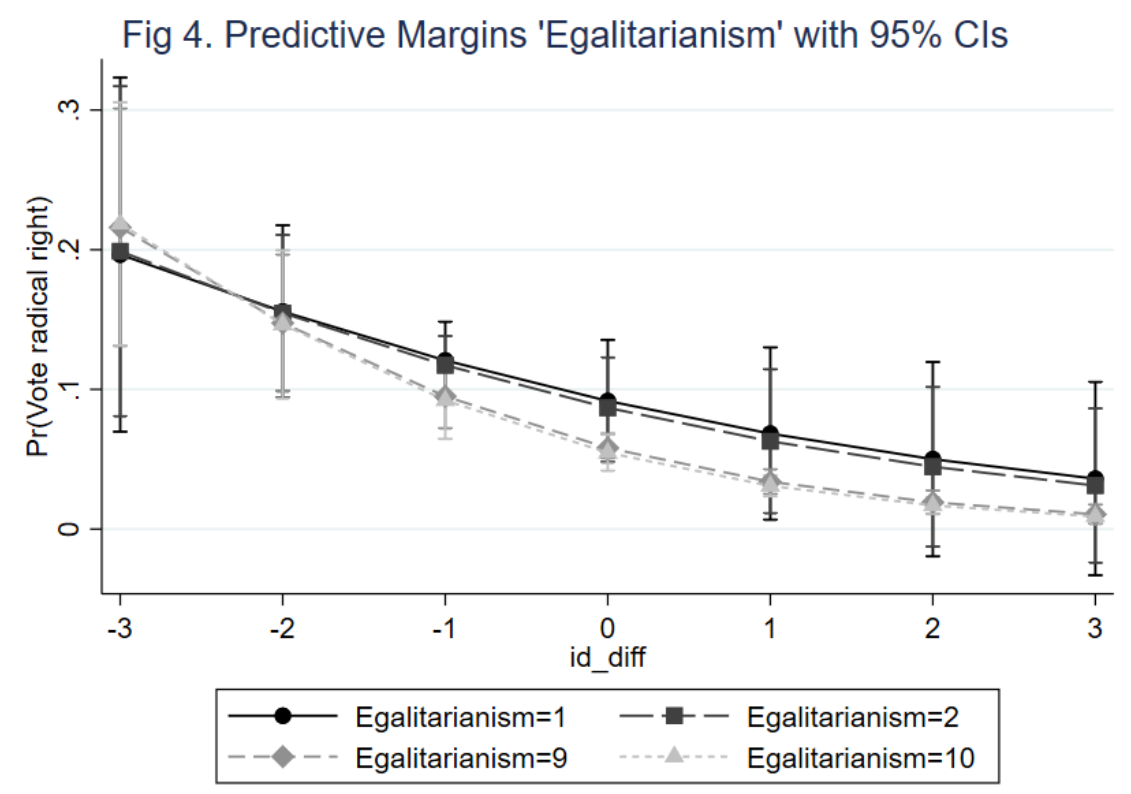

The Interaction between the attitudes towards Income inequality and Identity traits affecting the odds of voting of voting for a radical right party. Negative numbers (left) on the horizontal axis represent exclusive identity traits while positive numbers depict highly inclusive traits. High numbers on the egalitarian variable represent people who believe "Incomes should be made more equal", while low values represent respondents who think "We need larger income differences as incentives".

Figures ' 3 ' and ' 4 ' show similar analyses, but the DV is now the probability of voting for the radical right (against other type of parties) as a dependent variable. There is no noteworthy interaction between egalitarianism and identity traits: both highly egalitarian and egoistic voters present a high probability of voting for the radical right at exclusive identity traits, but the probability drops towards zero for both groups of voters if they have an inclusive conception of identity (figure 4). In the case of attitudes towards redistribution(figure 3), we see that among those voters who are strongly in favor of redistribution, the prediction is always close to zero, but for those voters who are 
opposed, there is a strong likelihood of voting for the radical right at the exclusive end of the graph, which goes down progressively as we approach the inclusive pole. In other words, voters with inclusive identity traits are unlikely to vote for the radical right, even if they believe that responsibility for people's welfare and livelihood lies solely with the individual and not the government.

Figure 5

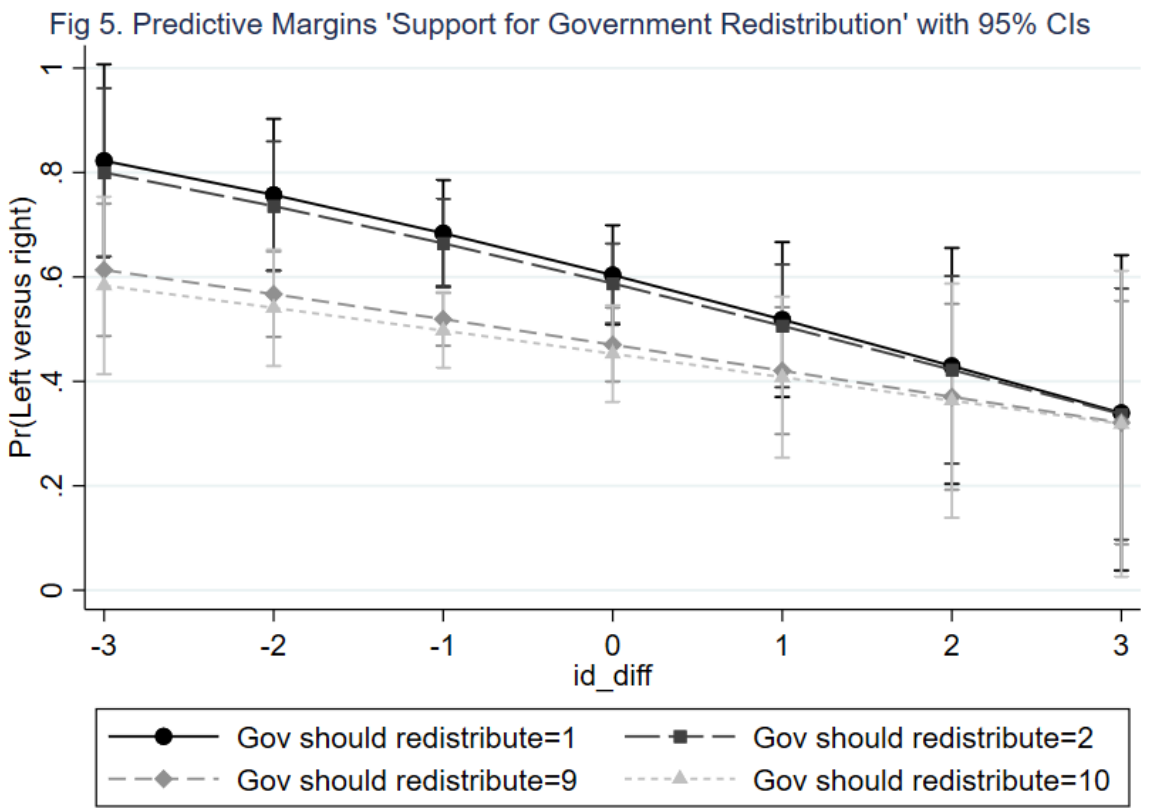

The Interaction between the attitudes towards government redistribution and Identity traits affecting the odds of voting for a radical right party as opposed to a radical left party. Negative numbers (left) on the horizontal axis represent exclusive identity traits while positive numbers depict highly inclusive traits. High numbers on the equality variable represent people who believe "The state should take more responsibility to ensure that everyone is provided for", while low values represent the opposite. 
Figure 6

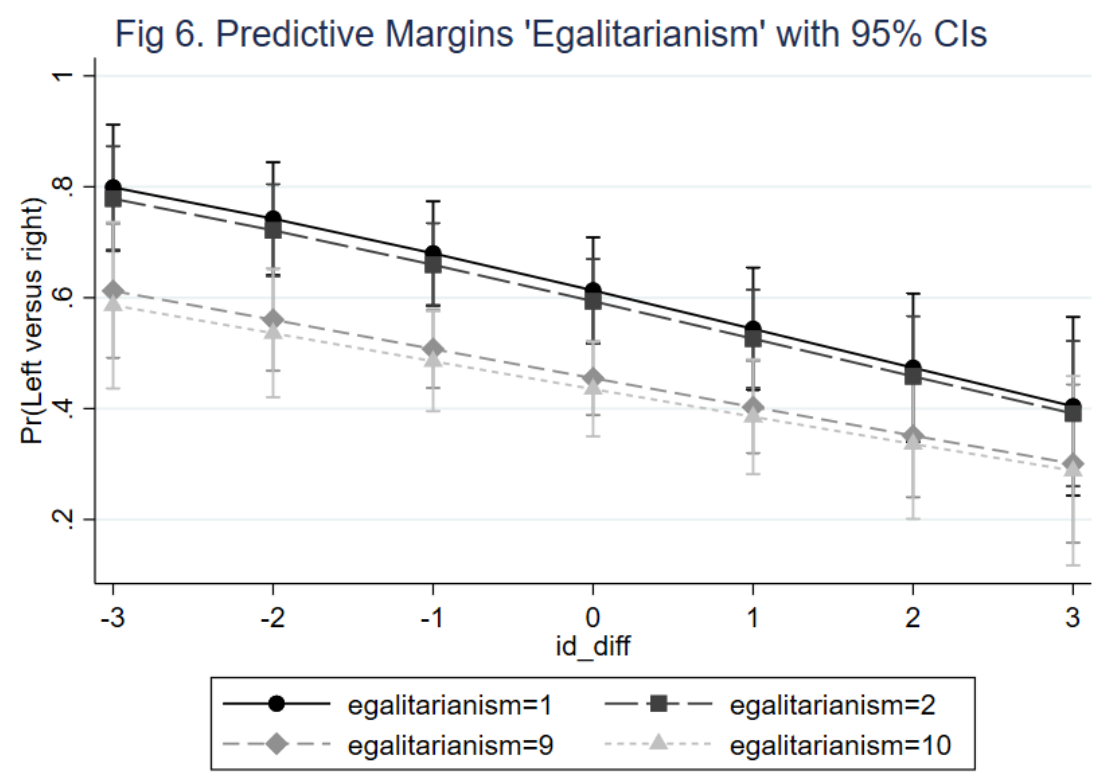

The Interaction between the attitudes towards Income inequality and Identity traits affecting the odds of voting for a radical right party as opposed to a radical left party. Negative numbers (left) on the horizontal axis represent exclusive identity traits while positive numbers depict highly inclusive traits. High numbers on the egalitarian variable represent people who believe "Incomes should be made more equal", while low values represent respondents who think "We need larger income differences as incentives”.

Figures Five and Six depict graphically similar analyses, only this time the probabilities displayed are not of voting for a radical party against the mainstream. Instead the graphs depict the interaction from models 9 and 12, in which the dependent variable was coded as 1 if the voter had voted for the radical right, and 0 if the voter had opted for the radical left. We thus compare radical voters directly against each others, not against a nonradical benchmark category, and the prediction shows the likelihood of voting for the radical right instead of the radical left. Figure 5 shows that anti-redistribution voters tend 
to be more likely to vote for the radical right instead of the radical left when they have exclusive identity traits, but this situation holds only in one instance: when the value of the exclusive identity indicator is ' -1 ', denoting slightly exclusive identity characteristics. Moving further left on the figure (more exclusive identity), the predictions grow further apart, but the error bars also increase, the results here thus being tentative and incomplete, Moving further right on the figure, the difference between the two types of voters decreases as they become more inclusive (the predictions merge for absolutely inclusive respondents). In figure six we find no significant difference between voters, regardless of the value of 'identity inclusiveness' - the only clear result is that ceteris paribus, exclusive identity voters prefer the right wing over the left wing.

When drawing the line with regards to redistributive values and attitudes, we find mixed evidence in support of hypothesis two. There is tentative evidence that highly 'redistributive' voters become less likely to vote for the radical left when they have a 'narrow' identity trait, or sense of belonging, but the probability rises when they feel more European than they feel national. The same does not, however, seem to hold true when it comes to egalitarianism. We also find the likelihood of voting for the radical right (with reference to non-radical voting and to voting for the radical left) to generally be stronger among those with exclusive identity traits (the exception being highly redistributive voters in figure 3). This seems to be particularly so when inspecting the relationship between egalitarianism and identity traits - exclusive identity traits lead to radical right voting, regardless how much individuals favor equality.

In the final part of the empirical analysis, we approach hypothesis three, which postulates that exclusive identity traits may interact with social class membership to explain radical 
voting tendencies . Figure 7 displays the predicted probability of voting for the radical right for three types of voters - those belonging to the upper class, lower middle class, and working class, across all ranges of personal identity conceptions.

Figure 7

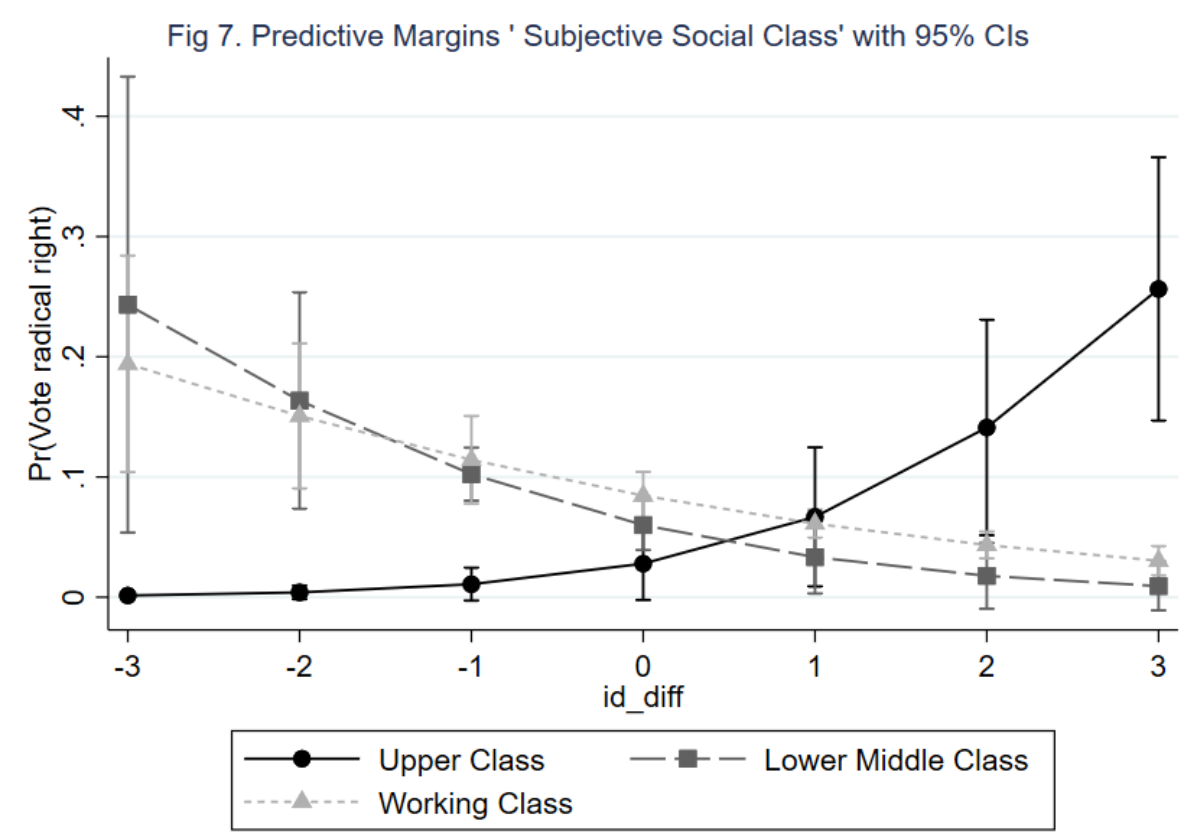

The Interaction between Identity traits and social class dummies affecting the odds of voting of voting for a radical right party. Negative numbers (left) on the horizontal axis represent exclusive identity traits while positive numbers depict highly inclusive traits.

We see that at highly exclusive identity traits (left pole) both working class and lower middle class voters (social classes 3 and 4 ) are more likely to vote for the radical right than upper class individuals, and that this probability decreases as such voters become ever more inclusive . This suggests that for working class and middle class individuals, the growing odds of voting for radical right parties are mediated by (exclusive) identity traits. 
Figure 8

Fig 8. Predictive Margins 'Subjective Social Class' with 95\% Cls

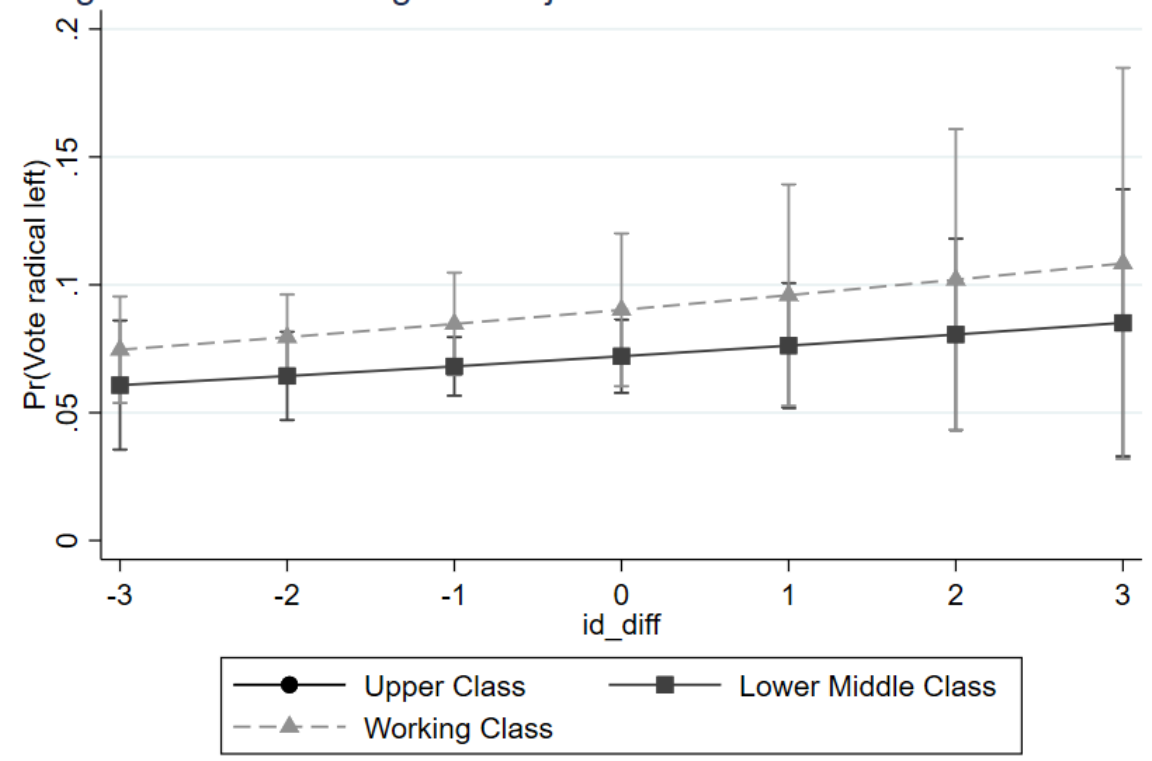

The Interaction between Identity traits and social class dummies affecting the odds of voting of voting for a radical left party. Negative numbers (left) on the horizontal axis represent exclusive identity traits while positive numbers depict highly inclusive traits.

On the radical left, both working class and lower middle class voters register growing probabilities of voting for the radical left as they become more inclusive. The small number of upper class voters opting for the radical left renders it impossible to plot the predictive margins for that category in figure 8 (in fact there is only on observation of an upper class respondent declaring a radical left vote intention). We argue that this relationship may underlie the issue concerns of voters that are often taken to explain populist and radical voting tendencies: economic concerns versus cultural (immigration concerns). Those voters with exclusive identity traits will be the ones more likely to adhere to the issue agenda of radical right parties, while those with inclusive identities 
will continue to vote in line with (assumed) concerns of the working class and lower middle class- the economic emphasis of radical left parties. This goes in line with the expectation of hypothesis 3 , according to which the polarization of the radical right vote can be explained by the identity structure of working-class voters. Those voters with larger in-groups will perceive the communities they are attached to as being less vulnerable to immigration and more stable, and feel less of an urgency to vote in a manner that protects said community. Thus, they can continue to focus on and vote in line with the traditional tenets of organized labor and socialist parties: economic redistribution, economic protectionism, social policy, maintaining the mixed economy that underlies the European Welfare State.

\section{Conclusion}

What explains the phenomenon of historically left-wing constituencies fuelling the rise of the Far Right in Europe over the past two decades? What sets apart the electorates of radical right and radical left parties, despite their similar socio-economic backgrounds and opposition to globalization? Following a strand of research that explored the relationship between support for EU policies and individual identity traits, this article shows that what distinguishes said radical party supporters is the difference between inclusive and exclusive identity traits. We argue that the extent to which individuals are able to identify with non-nationals and other Europeans (influences not only the likelihood of voting for radical right parties, but also mediates the effect of other factors on radical left voting. In contrast to previously held assumptions and findings (Rooduijn 
et al, 2017), we find evidence that it is possible for individuals who are egalitarian and support government redistribution to vote for the radical right. These findings speak to the literature on welfare chauvinism (Marx and Naumann, 2018; Schumacher and Van Kersbergen, 2014) and contribute to its ongoing development as well as that on populism. The baseline effect of egalitarianism and redistributive support is one of increasing likelihood of voting for the radical left, and decreasing likelihood of voting for the radical right. However, when combined with the presence of an exclusive conception of identity, the effect is more nuanced and can lead to the opposite outcome. Egalitarian voters and those supporting government redistribution are more likely to vote for the radical right if individual identity traits are highly exclusive.

These results point to further important questions that future research should address regarding individual identity traits and voting behavior. The literature on populist and radical party growth emphasizes the defection of voters from the political mainstream, and the left wing, to the right side of the political spectrum in explaining the rise of said fringe parties in Europe and beyond (De Lange, 2007; McGann and Kitschelt, 2005). This itself brings up the question of how such voters reconcile voting for the far right with their own political self-assessment. One question that merits further research is the degree to which current right wing voters (that formerly supported left wing parties) acquiesce to their description or characterization as far right or radical right (and radical left respectively). We speculate that the process of voting for the far right might lead to a delayed change in the political self-assessment of voters, but this remains an open avenue for upcoming research. Furthermore, given the strong performances of radical parties of 
various political colors and the diminishing strength of Europe's political center (in effect the flattening of election results to the benefit of the fringes) it becomes worthwhile to investigate how said self-political identification and acquiescence interacts with the growing polarization of electorates (Mueller and Tan, 2018, ). Increasing ideological divides among the public, as well as the trending mediatization of new cleavages (or confrontations between groups such as PEGIDA vs ANTIFA) speak to the growing discussion about so called 'echo-chambers' enabled by new social media, and their influence on political dialogue (Leeper, 2014).

\section{Bibliography}

Anderson B (1991) Imagined Communities: Reflections on the Origin and Spread of Nationalism. London: Verso.

Arzheimer K (2008) Die Wähler der extremen Rechten 1980-2002. Wiebaden: VS Verlag für Sozialwissenschaften, 2008

Bakker B N, Rooduijn M and Schumacher G (2015) "The Psychological Roots of Populist Voting: Evidence from the United States, the Netherlands and Germany." European Journal of Political Research 55 (2): 302-320.

Bakker B N (2016) “Personality traits, income and economic ideology”. Political Psychology. Doi: 10.1111/pops.12349

Bakker R, de Vries C, Edwards E, Hooghe L, Jolly S, Marks G, Polk J, Rovny J, Steenbergen M and Vachudova M (2015) "Measuring party positions in Europe: The Chapel Hill expert survey trend file, 1999-2010." Party Politics 21.1: 143152.

Beierlein, C, Kuntz, A, and Davidov, E (2016) Universalism, conservation, and attitudes toward minority groups. Social Science Research, 58, 68-79. 
Betz HG (1993) “The New Politics of Resentment: Radical Right-Wing Populist Parties in Western Europe," Comparative Politics 25: 413-27.

Brambor T, Clark W, \& Golder M (2006) “Understanding Interaction Models: Improving Empirical Analyses”. Political Analysis, 14(1), 63-82

Citrin J and Sides J (2004) Can Europe Exist without Europeans? Problems of Identity in a Multinational Community.

Cinpoes R (2008) "From National Identity to European Identity”. Journal of Identity and Migration Studies. 2. 1-14.

de Lange S L (2007) "A New Winning Formula?: The Programmatic Appeal of the Radical Right." Party Politics 13 (4): 411-435.

De Vries C E and Edwards E E (2009) "Taking Europe to its Extremes: Extremist Parties and Public Euroscepticism." Party Politics 15 (1): 5-28.

European Values Survey: https://europeanvaluesstudy.eu/European Values Study 19812008, Longitudinal Data File. GESIS Data Archive, Cologne, Germany, ZA4804 Data File Version 3.0.0 (2015-07-30), doi:10.4232/1.12253

Döring H and Manow P (2018) Parliaments and governments database (ParlGov): Information on parties, elections and cabinets in modern democracies. Development version. http://www.parlgov.org/

Gomez R, Morales L and Ramiro L (2016) "Varieties of Radicalism: Examining the Diversity of Radical Left Parties and Voters in Western Europe." West European Politics 39 (2): 351-379.

Goerres A, Spies D C and Kumlin S (2018) "The Electoral Supporter Base of the Alternative for Germany." Swiss Political Science Review 0 (0).

Greenfeld L (1999) ‘Is Nation Unavoidable? Is Nation Unavoidable Today?’ in Kriesi H, Armingeon K, Siegrist $\mathrm{H}$ and Wimmer A, (eds), Nation and National Identity: The European Experience in Perspective (Chur: Rüegger, 1999)

Halikiopoulou D, Kyriaki N and Vasilopolou S (2012) "The Paradox of Nationalism: The Common Denominator of Radical Right and Radical Left Euroscepticism." European Journal of Political Research 51 (4): 504-539. 
Harteveld E (2016) "Winning the 'losers' but Losing the 'winners'? the Electoral Consequences of the Radical Right Moving to the Economic Left." Electoral Studies 44: 225-234.

Hobsbawm E (1992) Nations and Nationalism since 1780: Programme, Myth, Reality. Cambridge: Cambridge University Press.

Hooghe L and Marks G (2004) "Does Identity Or Economic Rationality Drive Public Opinion on European Integration?" PS: Political Science \& Politics 37 (3): 415420.

Hooghe L and Marks G (2009) "A Postfunctionalist Theory of European Integration: From Permissive Consensus to Constraining Dissensus." British Journal of Political Science 39 (01): 1-23.

Hooghe L, Marks G and Wilson C J (2002) "Does Left/Right Structure Party Positions on European Integration?" Comparative Political Studies 35 (8): 965-989.

Inglehart R, Haerpfer C, Moreno A, Welzel C, Kizilova K, Diez-Medrano K, Lagos M, Norris P, Ponarin E and Puranen Bet al. (eds.). 2014. World Values Survey: All Rounds - Country-Pooled Datafile Version: http://www.worldvaluessurvey.org/WVSDocumentationWVL.jsp. Madrid: JD Systems Institute.

Ivarsflaten E (2005) "The Vulnerable Populist Right Parties: No Economic Realignment Fuelling their Electoral Success." European Journal of Political Research 44 (3): 465-492.

Katz, R and Mair P (1995) "Changing Models of Party Organization and Party Democracy: The Emergence of the Cartel Party." Party Politics 1 (1): 5-28

Klandermans B, Sabucedo J M and Rodriguez M (2004) "Inclusiveness of Identification among Farmers in the Netherlands and Galicia (Spain)." European Journal of Social Psychology 34 (3): 279-295.

Kitschelt H (with McGann, A J) (1995) The radical Right in Western Europe. Ann Arbor: University of Michigan Press.

Kitschelt H and McGann A J (1995) The Radical Right in Western Europe: A Comparative Analysis. Ann Arbor, MI:University of Michigan Press 
Kriesi H (2009) "Rejoinder to Liesbet Hooghe and Gary Marks, 'A Postfunctional Theory of European Integration: From Permissive Consensus to Constraining Dissensus'." British Journal of Political Science 39 (1): 221-224.

Kriesi H, Grande E, Dolezal M, Helbling M, Höglinger D, Hutter S and Wüest B (2012). Political Conflict in Western Europe Cambridge University Press.

Kriesi H, Grande e, Lachat R, Dolezal M, Bornschier S, and Frey T (2008) West European Politics in the Age of Globalization Cambridge University Press.

Leeper T J ( 2014) “The Informational Basis for Mass Polarization”. Public Opinion Quarterly, 78, 27.

Lefkofridi Z, Wagner M, and Willmann J E (2014) "Left-Authoritarians and Policy Representation in Western Europe: Electoral Choice Across Ideological Dimensions." West European Politics 37 (1): 65-90.

Lubbers M and Jaspers E (2011) "A Longitudinal Study of Euroscepticism in the Netherlands: 2008 Versus 1990." European Union Politics 12 (1): 21-40. Lubbers M, Gijsberts M and Scheepers P (2002) "Extreme Right-Wing Voting in Western Europe." European Journal of Political Research 41 (3): 345-378. Mair P (2001) “The Green Challenge and Political Competition: How Typical is the German Experience?”, German Politics, 10:2, 99-116

March L (2011) Radical Left Parties in Contemporary Europe. Abingdon: Routledge. March L and Rommerskirchen C (2015) "Out of Left Field? Explaining the Variable Electoral Success of European Radical Left Parties." Party Politics 21 (1): 40-53. Marks G and Steenbergen M R (2004) European Integration and Political Conflict Cambridge University Press.

Marks G and Wilson C J (2000) "The Past in the Present: A Cleavage Theory of Party Response to European Integration." British Journal of Political Science 30 (03): 433-459.

Marx P and Naumann E (2018) Do Right-Wing Parties Foster Welfare Chauvinistic Attitudes? A Longitudinal Study of the 2015 'refugee Crisis' in Germany. Vol. 52. McLaren L (2007) "Explaining Mass-Level Euroscepticism: Identity, Interests, and Institutional Distrust." Acta Politica 42 (2): 233-251. 
McGann A J and Kitschelt H (2005) "The Radical Right in the Alps." Party Politics 11 (2): $147-171$.

Meguid B M (2008) Party Competition between Unequals: Strategies and Electoral Fortunes in Western Europe Cambridge University Press.

Mudde C (2004) "The Populist Zeitgeist." Government and Opposition 39 (4): 541-563. Mudde C (2016) The Study of Populist Radical Right Parties: Towards a Fourth Wave. C-REX Working Paper Series. 1/26

Mueller S T and Tan Y-Y S (2018) "Cognitive perspectives on opinion dynamics: the role of knowledge in consensus formation, opinion divergence, and group polarization”. Journal of Computational Social Science, 1, 15-48

Oesch D (2008) "Explaining Workers' Support for Right-Wing Populist Parties in Western Europe: Evidence from Austria, Belgium, France, Norway, and Switzerland." International Political Science Review 29 (3): 349-373.

Polk J, Rovny J, Bakker R, Edwards E, Hooghe L, Jolly S, Koedam J, Kostelka F, Marks G, Schumacher G, Steenbergen M, Vachudova M and Zilovic M (2017) "Explaining the salience of anti-elitism and reducing political corruption for political parties in Europe with the 2014 Chapel Hill Expert Survey data," Research \& Politics (January-March): 1-9.

Risse T (2003) “Nationalism and Collective Identities. Europe versus the Nation-State?” In Developments in West European Politics, Heywood P, Jones E, and Rhodes M(eds) (2003). London: Palgrave Macmillan.

Risse, T (2005) "Neofunctionalism, European Identity, and the Puzzles of European Integration”. Journal of European Public Policy. 12, 2, 291-309.

Rooduijn M and Akkerman T (2017) "Flank Attacks: Populism and Left-Right Radicalism in Western Europe." Party Politics 23 (3): 193-204.

Rooduijn M, Burgoon B, van Elsas E and van de Werfhorst H G (2017) "Radical Distinction: Support for Radical Left and Radical Right Parties in Europe." European Union Politics 18 (4): 536-559.

Rydgren J (2005) "Is Extreme Right-Wing Populism Contagious? Explaining the Emergence of a New Party Family." European Journal of Political Research 44 (3): 413-437. 
Schumacher G and van Kersbergen K (2014) "Do Mainstream Parties Adapt to the Welfare Chauvinism of Populist Parties?" Party Politics.

Schwartz S H (1992) Universals in the content and structure of values: theoretical advances and empirical tests in 20 countries. In Berkowitz L and Zanna M P (Eds.) (1992), Advances in experimental social psychology (pp. 1-65). San Diego: Academic Press.

Skocpol T and Amenta E (1986) "States and Social Policies.".Annual Review of Sociology 12 (1): 131-157.

Smith, Anthony D. 1986. The Ethnic Origins of Nations. Oxford: Blackwell. Spies D and Franzmann S T(2011): “A Two-Dimensional Approach to the Political Opportunity Structure of Extreme Right Parties in Western Europe”, West European Politics, 34:5, 1044-1069

Spies D (2013) "Explaining Working-Class Support for Extreme Right Parties: A Party Competition Approach." Acta Politica 48 (3): 296-325.

Swank D and Betz H-G (2003) “Globalization, the Welfare State and Right-Wing Populism in Western Europe,” Socio-Economic Review 1(2): 215-45

Szczerbiak A and Taggart P (2008) Opposing Europe?: The Comparative Party Politics of Euroscepticism: Volume 2: Comparative and Theoretical Perspectives OUP Oxford.

Tamir Y (1995) “The Enigma of Nationalism”. World Politics, 47(3), 418-440.

Teney C, Lacewell OP and De Wilde P (2014) "Winners and Losers of Globalization in Europe: Attitudes and Ideologies." European Political Science Review 6 (4): 575595. doi:10.1017/S1755773913000246.

Thomassen J (2012) "The Blind Corner of Political Representation." Representation 48 (1): $13-27$.

van Biezen I (2004) “Political Parties as Public Utilities”. Party Politics, 10(6), 701-722 Van der Brug W and van Spanje J (2009) "Immigration, Europe and the ?New? Cultural Dimension." European Journal of Political Research 48 (3): 309-334.

van der Waal, PA, Houtman D, de Koster W and Manevska K (2010) "‘Some are More Equal than Others': Economic Egalitarianism and Welfare Chauvinism in the Netherlands." Journal of European Social Policy 20 (4): 350-363. 
van Elsas E J (2017) Appealing to the 'losers'? the Electorates of Left-Wing and RightWing Eurosceptic Parties Compared, 1989-2014. Vol. 50.

van Elsas, E J and van der Brug W (2014) "The Changing Relationship between leftright Ideology and Euroscepticism, 1973-2010." European Union Politics.

Van Kersbergen K (2000) "Political Allegiance and European Integration." European Journal of Political Research 37 (1): 1-17.

van Spanje J (2010) "Contagious Parties: Anti-Immigration Parties and their Impact on Other Parties" Immigration Stances in Contemporary Western Europe." Party Politics 16 (5): 563-586.

Visser M, Lubbers M, Kraaykamp G, and Jaspers E (2014) "Support for Radical Left Ideologies in Europe." European Journal of Political Research 53 (3): 541-558.

Weber W and Willem S (2015) “The relationship between issues and an individual's left-right orientation “ Acta Politica 50: 193. 193-213

Werts H, Scheepers P and Lubbers M (2013) "Euro-Scepticism and Radical Right-Wing Voting in Europe, 2002-2008: Social Cleavages, Socio-Political Attitudes and Contextual Characteristics Determining Voting for the Radical Right." European Union Politics 14 (2): 183-205. 